\title{
Kemampuan Berpikir Kreatif dan Hasil Belajar Matematika Siswa Menggunakan Model Pembelajaran Project-Based Learning Berbasis Pendekatan STEM
}

\author{
I Wayan Widana ${ }^{1 *}$, Kadek Lisa Septiari ${ }^{2}$ \\ ${ }^{1,2}$ Program Studi Pendidikan Matematika, Universitas PGRI Mahadewa Indonesia \\ *i.wayan.widana.bali@gmail.com
}

\begin{abstract}
Abstrak
Berpikir kreatif merupakan salah satu kompetensi yang diperlukan pada era Revolusi Industri 4.0 di mana perubahan terjadi sangat cepat dan dinamis, sehingga harus diimbangi dengan cara berpikir yang tidak rutin atau kemampuan memunculkan gagasan-gagasan baru. Penelitian ini bertujuan untuk menganalisis pengaruh model pembelajaran project-based learning berbasis pendekatan STEM terhadap kemampuan berpikir kreatif dan hasil belajar matematika. Populasi penelitian adalah siswa kelas VII SMP PGRI 6 Denpasar. Pemilihan sampel kelas eksperimen dan kelas kontrol menggunakan teknik random sampling. Kelas eksperimen diberikan perlakuan model pembelajaran project-based learning berbasis pendekatan STEM sedangkan kelompok kontrol menggunakan model pembelajaran project-based learning biasa. Jenis penelitian adalah quasi experiment dengan desain non equivalen post-test only control group design. Data kemampuan berpikir kreatif dikumpulkan menggunakan kuesioner dan data hasil belajar matematika dikumpulkan menggunakan tes uraian. Data dianalisis menggunakan uji Manova. Berdasarkan hasil analisis data diperoleh terdapat pengaruh model pembelajaran project-based learning berbasis pendekatan STEM terhadap kemampuan berpikir kreatif; terdapat pengaruh model pembelajaran project-based learning berbasis pendekatan STEM terhadap hasil belajar matematika; dan terdapat pengaruh model pembelajaran project-based learning berbasis pendekatan STEM secara bersama-sama terhadap kemampuan berpikir kreatif dan hasil belajar matematika.
\end{abstract}

Kata kunci: berpikir kreatif, hasil belajar matematika, model project-based learning, pendekatan STEM

\begin{abstract}
Creative thinking is one of the competencies needed in the Industrial Revolution 4.0, where change is very dynamic, so it must be balanced with an irregular way of thinking. This study analyzes the effect of the project-based learning models on the STEM approach to creative thinking skills and mathematics learning outcomes. The population was grade VII students of SMP PGRI 6 Denpasar in the 2019/2020 school year. The sample of the experimental class and the control class used the random sampling technique. The experimental class was given treatment with a project-based learning model based on the STEM approach, while the control group used a conventional project-based learning model. Data on creative thinking skills were collected using a questionnaire, and data on mathematics learning outcomes were collected using essay tests. Data were analyzed using the Manova test. The results of the study: there is an effect of the STEM approach-based project-based learning model on creative thinking skills; there is an effect of project-based learning model based on STEM approach on mathematics learning outcomes; there is an effect of the project-based learning model based on the STEM approach together on creative thinking skills and mathematics learning outcomes.
\end{abstract}

Keywords: creative thinking, mathematics learning outcomes, project-based learning model, STEM approach 


\section{Pendahuluan}

Berpikir kreatif (creative thinking) merupakan salah satu kompetensi yang diperlukan pada era Revolusi Industri 4.0 di mana perubahan terjadi sangat cepat dan dinamis, sehingga harus diimbangi dengan cara berpikir yang tidak rutin atau kemampuan memunculkan gagasangagasan baru. Kompetensi tersebut menjadi sesuatu yang sangat urgen agar peserta didik mampu beradaptasi dalam lingkungan yang selalu berubah dan serba tidak pasti (Widana, 2020). Kemampuan berpikir kreatif harus dilatih melalui pembelajaran matematika berbasis teknologi informasi, sehingga ciri khas matematika yaitu penalaran dan logika menjadi landasan untuk mengembangkan kemampuan berpikir kreatif.

Sudiarta dan Widana (2019) menyatakan bahwa permasalahan-permasalahan matematika yang berbasis pada masalah kontekstual, mampu menghubungkan konsep-konsep matematika yang abstrak dengan dunia nyata dalam kehidupan sehari-hari, sehingga manfaat belajar matematika dapat dirasakan secara langsung oleh pembelajar. Pada umumnya pemecahan masalah kontekstual, diawali dengan pemodelan matematika (rekayasa/engineering). Untuk menyelesaikan model matematika tersebut dapat menggunakan teknologi informasi sehingga penyelesaian masalah dapat dilakukan dengan cepat dan lebih sederhana (Nafiah \& Suyanto, 2014). Pendekatan STEM (Science, Technology, Engineering, Mathematics) dalam pembelajaran mampu menghubungkan konsep matematika secara teoretik berbasis teknologi informasi dengan permasalahan kontekstual dalam kehidupan sehari-hari.

Hasil studi pendahuluan menunjukkan bahwa kemampuan berpikir kreatif siswa-siswa di Indonesia sangat rendah. Hal ini dapat dilihat dari studi internasional PISA pada aspek literasi matematika, bahwa prestasi siswa-siswa di Indonesia sangat rendah terutama menggunakan konsep matematika untuk memecahkan masalah kontekstual (Nilasari \& Anggreini, 2019). Temuan ini sejalan dengan penelitian yang dilakukan oleh Mawardhiyah dan Manoy (2018) yang menyatakan bahwa kemampuan berpikir kreatif siswa SMP sangat rendah sebagai dampak dari model pembelajaran yang digunakan guru tidak mengarah pada pengembangan kemampuan berpikir kreatif menyelesaikan masalah kontekstual, tetapi lebih menekankan penguasaan matematika secara konseptual teoretik.

Berdasarkan uraian di atas, maka guru-guru matematika harus mampu dan kreatif memilih model pembelajaran yang dikombinasikan dengan pendekatan yang sesuai, serta berbasis teknologi informasi. Ciri model pembelajaran yang baik adalah adanya keterlibatan intelektual-emosional peserta didik, menganalisis, berbuat, dan pembentukan sikap; adanya keikutsertaan peserta didik secara aktif dan kreatif selama proses pembelajaran; guru bertindak 
sebagai fasilitator, koordinator, mediator dan motivator kegiatan belajar; dan penggunaan berbagai pendekatan, alat, dan media pembelajaran (Hidayat, dkk., 2019).

Model pembelajaran project-based learning adalah model pembelajaran berbasis proyek yang menitikberatkan pada proses mental intelektual untuk memecahkan berbagai persoalan yang dihadapi, sehingga menemukan suatu konsep atau generalisasi yang dapat diterapkan dalam pemecahan masalah (Redkar, 2012). Peran guru adalah sebagai fasilitator di mana ia akan membantu peserta didik dalam proses belajar ketika ia dibutuhkan. Pada model pembelajaran ini guru memberikan kesempatan sepenuhnya kepada peserta didik untuk menuangkan gagasan-gagasan sehingga dapat memberikan rangsangan positif bagi peserta didik baik secara fisik maupun mental dalam rangka menemukan konsep baru (Zhou, 2012).

Implementasi model pembelajaran project-based learning dalam pembelajaran matematika perlu dikombinasikan dengan pendekatan STEM yang sesuai dengan tuntutan Revolusi Industri 4.0. Carlisle dan Weaver (2018) dan Association of American Universities (2013) menyatakan bahwa pendekatan STEM dalam pembelajaran matematika memiliki beberapa keunggulan, di antaranya: (1) transformasi proses pendidikan yang mampu menghilangkan batas pemisah antara subjek sains, matematika, teknologi, dan rekayasa; (2) peningkatan keterampilan saintifik dan literasi sains; (3) pengembangan SDM relevan di abad ke-21 seperti kemampuan dalam berkolaborasi, berkomunikasi, berpikir secara kreatif, dan memiliki kemampuan dalam mengembangkan kreativitasnya; (4) tantangan teknologi melalui proses desain rekayasa untuk menyederhanakan solusi permasalahan; (5) meningkatkan motivasi belajar melalui proses pembelajaran berbasis masalah kontekstual untuk mengembangkan kemampuan problem solving.

Beberapa penelitian relevan telah dilakukan sebelumnya hanya fokus pada penerapan model pembelajaran project-based learning murni, tanpa dipadukan dengan pendekatan STEM seperti pada penelitian ini, antara lain: (1) Rahma Wahyu (2016), dengan fokus penelitiannya adalah penerapan model pembelajaran project-based learning dalam upaya meningkatkan hasil belajar siswa SMP untuk mendukung implementasi Kurikulum 2013; (2) Yulita Dyah Kristanti, dkk (2016), membandingkan hasil belajar fisika siswa SMA melalui penerapan model pembelajaran project-based learning dan model pembelajaran langsung (direct instruction); (3) Aldabbus, S. (2018), melakukan penelitian terhadap guru-guru sekolah dasar terkait dengan peluang dan tantangan implementasi model pembelajaran project-based learning; (4) Chiang \& Lee (2016) melakukan studi tentang pengaruh model pembelajaran project-based learning terhadap motivasi dan kemampuan pemecahan masalah pada siswa SMK di Taiwan; (5) Melda Ariyanti (2017), dalam penelitiannya yang membandingkan keefektifan model project-based 
learning dan problem-based learning ditinjau dari ketercapaian tujuan pembelajaran di SMA Negeri 2 Kuningan. Perbedaan penelitian ini dengan penelitian sebelumnya adalah fokus pada implementasi model pembelajaran project-based learning berbasis pendekatan STEM.

Berdasarkan hasil kajian teoretik dan beberapa hasil penelitian relevan terdahulu, maka rumusan masalah yang dikaji dalam penelitian ini adalah: (1) apakah terdapat pengaruh model pembelajaran project-based learning berbasis pendekatan STEM terhadap kemampuan berpikir kreatif?; (2) apakah terdapat pengaruh model pembelajaran project-based learning berbasis pendekatan STEM terhadap hasil belajar matematika?; dan (3) apakah terdapat pengaruh model pembelajaran project-based learning berbasis pendekatan STEM secara bersama-sama terhadap kemampuan berpikir kreatif dan hasil belajar matematika?

\section{Metode}

Penelitian ini menggunakan pendekatan kuantitatif, jenis penelitian eksperimen semu (quasi experiment) dan desain penelitian non-equivalen post-test only control group design. Populasi penelitian adalah kelas VII SMP PGRI 6 Denpasar tahun pelajaran 2019/2020. Pemilihan sampel kelas eksperimen dan kontrol menggunakan teknik random sampling. Sampel kelas eksperimen berjumlah 30 orang terdiri dari 18 orang siswa perempuan dan 12 orang siswa laki-laki, sedangkan kelas kontol berjumlah 30 orang terdiri dari 16 orang siswa perempuan dan 14 orang siswa laki-laki. Pada kelas eksperimen diberikan perlakukan berupa model pembelajaran project-based learning berbasis pendekatan STEM sedangkan pada kelas kontrol diimplementasikan model pembelajaran project-based learning biasa tanpa pendekatan STEM.

Langkah-langkah model pembelajaran project-based learning menurut Mali (2016) adalah (1) start with the essential question, pertanyaan penugasan peserta didik dalam melakukan suatu aktivitas; (2) design a plan for the project, menyusun perencanaan aktivitas proyek; (3) create a schedule, guru dan peserta didik secara kolaboratif menyusun jadwal menyelesaikan proyek; (4) monitor the students and the progress of the project, guru melakukan monitor terhadap aktivitas peserta didik selama menyelesaikan proyek, berperan menjadi mentor, dan merekam keseluruhan aktivitas proyek; (5) assess the outcome, mengevaluasi kemajuan dan memberi umpan balik tentang aktivitas proyek yang telah dicapai; dan (6) evaluate the experience, melakukan evaluasi dan refleksi terhadap aktivitas dan hasil proyek yang sudah dijalankan. Peserta didik diminta untuk mengungkapkan perasaan dan pengalamanya selama menyelesaikan proyek, melalui diskusi, sehingga pada akhirnya diperoleh temuan baru (new inquiry) untuk menjawab permasalahan yang diajukan. 
Data kemampuan berpikir kreatif dikumpulkan menggunakan kuesioner yang dikembangkan sendiri oleh peneliti berjumlah 30 pernyataan/pertanyaan menggunakan skala Likert. Namun dari 30 pertanyaan/pernyataan itu, hanya 25 butir dinyatakan valid yang digunakan untuk mengambil data, dengan skor reliabilitas 0,907. Data hasil belajar matematika dikumpulkan menggunakan tes bentuk uraian yang berjumlah 5 butir yang dinyatakan valid dari 8 butir soal yang dikembangkan sebelumnya. Tes dikembangkan sendiri oleh peneliti berdasarkan indikator soal yang diturunkan dari Kompetensi Dasar, dengan skor reliabilitas sebesar 0,623. Validitas instrumen penelitian diuji menggunakan korelasi Product Moment Pearson, sedangkan reliabilitas instrumen diuji menggunakan rumus Alpha Croncbach. Data hasil penelitian dianalisis menggunakan uji Manova berbantuan program SPSS $23.0(\alpha=0,05)$. Sebelum diuji manova, terlebih dahulu dilakukan uji persyaratan analisis meliputi uji normalitas, uji homogenitas varians, uji homogenitas matriks varians/kovarians, dan uji multikolinearitas variabel tak bebas.

\section{Hasil Penelitian}

Setelah diimplementasikan model pembelajaran project-based learning berbasis pendekatan STEM pada kelas eksperimen dan model pembelajaran project-based learning pada kelas kontrol diperoleh data hasil penelitian kemampuan berpikir kreatif dan hasil belajar matematika siswa seperti pada tabel 1 berikut.

Tabel 1. Data Hasil Penelitian

\begin{tabular}{lrrrr}
\hline \multirow{2}{*}{ Statistik } & \multicolumn{2}{c}{ Kelompok Eksperimen } & \multicolumn{2}{c}{ Kelompok Kontrol } \\
\cline { 2 - 5 } & $\begin{array}{c}\text { Berpikir } \\
\text { Kreatif }\end{array}$ & $\begin{array}{c}\text { Hasil } \\
\text { Belajar }\end{array}$ & $\begin{array}{c}\text { Berpikir } \\
\text { Kreatif }\end{array}$ & $\begin{array}{c}\text { Hasil } \\
\text { Belajar }\end{array}$ \\
\hline Mean & 88,63 & 85,00 & 82,37 & 75,57 \\
\hline Median & 89,63 & 85,63 & 83,31 & 75,93 \\
\hline Modus & 89,83 & 86,25 & 85,50 & 77,0 \\
\hline SD & 8,12 & 7,31 & 9,75 & 7,78 \\
\hline Nilai minimum & 72 & 68 & 64 & 60 \\
\hline Nilai maksimum & 104 & 98 & 100 & 91 \\
\hline
\end{tabular}

Pada tabel 1 di atas, terlihat bahwa terdapat perbedaan mean kemampuan berpikir kreatif dan hasil belajar matematika antara kelas eksperimen dan kelas kontrol. Demikian pula pada statistik median, modus, serta maksimum dan minimum menunjukkan adanya perbedaan. Namun perbedaan-perbedaan tersebut perlu diuji lebih lanjut apakah perbedaan tersebut signifikan atau tidak menggunakan analisis Manova.

Hasil uji persyaratan analisis terhadap data kemampuan berpikir kreatif dan hasil belajar matematika untuk kelas eksperimen dan kelas kontrol adalah sebagai berikut. 
Tabel 2. Hasil Uji Normalitas Berpikir Kreatif Kelas Eksperimen Tests of Normality

\begin{tabular}{lrrrrrr}
\hline & \multicolumn{3}{c}{ Kests of Normality } & \multicolumn{3}{c}{ Shapiro-Wilk } \\
\cline { 2 - 7 } & Statistic & df & Sig. & Statistic & df & Sig. \\
\hline Berpikir_kreatif_ekspr &, 096 & 30 &, 200 &, 980 & 30 &, 836 \\
\hline $\begin{array}{l}\text { *. This is a lower bound of the true significance. } \\
\text { a. Lilliefors Significance Correction }\end{array}$ & & & & & &
\end{tabular}

Pada tabel 2 di atas terlihat nilai sig. $=0,836>0,05$ berarti bahwa data kemampuan berpikir kreatif kelas eksperimen berdistribusi normal.

Tabel 3. Hasil Uji Normalitas Berpikir Kreatif Kelas Kontrol Tests of Normality

\begin{tabular}{lrrrrrr}
\hline & \multicolumn{3}{c}{ Kolmogorov-Smirnov $^{\text {a }}$} & \multicolumn{3}{c}{ Shapiro-Wilk } \\
\cline { 2 - 7 } & Statistic & df & Sig. & Statistic & df & Sig. \\
\hline Berpikir_kreatif_kontrol &, 090 & 30 &, 200 &, 970 & 30 &, 534 \\
\hline *. This is a lower bound of the true significance. & & & & & \\
a. Lilliefors Significance Correction & & & & & &
\end{tabular}

Pada tabel 3 di atas terlihat nilai sig. $=0,534>0,05$ berarti bahwa data kemampuan berpikir kreatif kelas kontrol berdistribusi normal.

Tabel 4. Hasil Uji normalitas Hasil Belajar Kelas Eksperimen Tests of Normality

\begin{tabular}{lrrrrrr}
\hline & \multicolumn{3}{c}{ Kolmogorov-Smirnov $^{\text {a }}$} & \multicolumn{3}{c}{ Shapiro-Wilk } \\
\cline { 2 - 7 } & Statistic & df & Sig. & Statistic & df & Sig. \\
\hline Hasil_Belajar_Eksper &, 125 & 30 &, 200 &, 956 & 30 &, 521 \\
\hline *. This is a lower bound of the true significance. & & & & & \\
a. Lilliefors Significance Correction & & & & & &
\end{tabular}

Pada tabel 4 di atas terlihat nilai sig. $=0,521>0,05$ berarti bahwa data hasil belajar kelas eksperimen berdistribusi normal.

Tabel 5. Hasil Uji Normalitas Hasil Belajar Kelas Kontrol

Tests of Normality

\begin{tabular}{lrrrrrr}
\hline & \multicolumn{3}{c}{ Kolmogorov-Smirnov $^{\text {a }}$} & \multicolumn{3}{c}{ Shapiro-Wilk } \\
\cline { 2 - 7 } & Statistic & df & Sig. & Statistic & df & Sig. \\
\hline Hasil_Belajar_Kontrol &, 101 & 30 &, 200 &, 976 & 30 &, 700 \\
\hline *. This is a lower bound of the true significance. & & & & & \\
a. Lilliefors Significance Correction & & & & & &
\end{tabular}

Pada tabel 5 di atas terlihat nilai sig. $=0,700>0,05$ berarti bahwa data hasil belajar kelas kontrol berdistribusi normal.

Tabel 6. Hasil Uji Homogenitas Berpikir Kreatif Levene's Test of Equality of Error Variances ${ }^{\mathrm{a}}$ Dependent Variable: Berpikir_kreatif

\begin{tabular}{lrrr}
\hline $\mathbf{F}$ & df1 & df2 & Sig. \\
\hline 2,060 & 1 & 58 &, 157 \\
\hline *. This is a lower bound of the true significance. \\
a. Lilliefors Significance Correction
\end{tabular}

Pada tabel 6 di atas terlihat nilai sig. $=0,157>0,05$ berarti bahwa data kemampuan berpikir kreatif mempunyai varian yang homogen. 
Tabel 7. Hasil Uji Homogenitas Hasil Belajar Levene's Test of Equality of Error Variances ${ }^{\mathrm{a}}$

Dependent Variable: Hasil_belajar

\begin{tabular}{lccc}
\hline F & df1 & df2 & Sig. \\
\hline, 198 & 1 & 58 &, 658 \\
\hline *. This is a lower bound of the true significance. \\
a. Lilliefors Significance Correction
\end{tabular}

Pada tabel 7 di atas terlihat nilai sig. $=0,658>0,05$ sehingga dapat disimpulkan bahwa data hasil belajar mempunyai varian yang homogen.

Tabel 8. Hasil Uji Homogenitas Matriks Varians/Kovarians

Box's Test of Equality of Covariance Matrices

\begin{tabular}{lr}
\hline Box's M & 1,590 \\
F &, 510 \\
df1 & 3 \\
df2 & 605520,000 \\
Sig. &, 675 \\
\hline
\end{tabular}

Perhatikan tabel 8 pada Box's Test of Equality of Covariance Matrices di atas, nilai sig. $=0,675>0,05$, sehingga variabel terikat kemampuan berpikir kreatif dan hasil belajar matematika mempunyai matriks varian/kovarian yang sama.

Tabel 9. Hasil Uji Multikolinearitas

\begin{tabular}{|c|c|c|c|c|c|c|c|c|}
\hline & \multirow{2}{*}{ Model } & \multicolumn{2}{|c|}{$\begin{array}{l}\text { Unstandardize } \\
\text { d Coefficients }\end{array}$} & \multirow{2}{*}{$\begin{array}{l}\text { Standardized } \\
\text { Coefficients } \\
\text { Beta }\end{array}$} & \multirow{2}{*}{$\mathbf{t}$} & \multirow{2}{*}{ Sig. } & \multicolumn{2}{|c|}{$\begin{array}{l}\text { Collinearity } \\
\text { Statistics }\end{array}$} \\
\hline & & B & $\begin{array}{l}\text { Std. } \\
\text { Error }\end{array}$ & & & & $\begin{array}{l}\text { Toleranc } \\
\text { e }\end{array}$ & VIF \\
\hline \multirow[t]{3}{*}{1} & (Constant) & 3,460 &, 052 & & 7,250 & ,000 & & \\
\hline & Berpikir_kreatif &, 013 & 009 & ,258 & 1,507 & 137 & ,393 & 2,542 \\
\hline & Hasil_belajar &,- 041 & ,009 &,- 764 & $-4,462$ &, 000 & ,393 & 2,542 \\
\hline
\end{tabular}

Perhatikan tabel 9 di atas, terlihat bahwa nilai Collinearity Statistics pada variabel kemampuan berpikir kreatif dengan nilai toleransi sebesar 0,393>0,1 dan nilai VIF yaitu 2,542<10 maka dapat disimpulkan bahwa tidak menunjukkan gejala multikonearitas, demikian pula variabel hasil belajar matematika dengan nilai toleransi sebesar $0,393>0,1$ dan nilai VIF yaitu 2,542<10 maka dapat disimpulkan bahwa tidak tidak menunjukkan gejala multikonearitas.

Tabel 10. Hasil Analisis Parsial

Tests of Between-Subjects Effects

\begin{tabular}{llrrrrr}
\hline \multicolumn{1}{c}{ Source } & $\begin{array}{c}\text { Dependent } \\
\text { Variable }\end{array}$ & $\begin{array}{c}\text { Type III Sum } \\
\text { of Squares }\end{array}$ & df & \multicolumn{1}{c}{$\begin{array}{c}\text { Mean } \\
\text { Square }\end{array}$} & F & Sig. \\
\hline Corrected Model & Berpikir_kreatif & $633,750^{\mathrm{a}}$ & 1 & 633,750 & 7,428 &, 008 \\
& Hasil_belajar & $1664,267^{\mathrm{b}}$ & 1 & 1664,267 & 26,899 &, 000 \\
\hline Intercept & Berpikir_kreatif & 442900,417 & 1 & 442900,417 & 5190,764 &, 000 \\
& Hasil_belajar & 389459,267 & 1 & 389459,267 & 6294,788 &, 000 \\
\hline Kelas & Berpikir_kreatif & 633,750 & 1 & 633,750 & 7,428 &, 008 \\
& Hasil_belajar & 1664,267 & 1 & 1664,267 & 26,899 &, 000 \\
\hline Error & Berpikir_kreatif & 4948,833 & 58 & 85,325 & & \\
\hline
\end{tabular}




\begin{tabular}{llrrrrr}
\hline Source & $\begin{array}{c}\text { Dependent } \\
\text { Variable }\end{array}$ & $\begin{array}{c}\text { Type III Sum } \\
\text { of Squares }\end{array}$ & df & $\begin{array}{c}\text { Mean } \\
\text { Square }\end{array}$ & F & Sig. \\
\hline Total & Hasil_belajar & 3588,467 & 58 & 61,870 & \\
& Berpikir_kreatif & 448483,000 & 60 & & \\
& Hasil_belajar & 394712,000 & 60 & & \\
\hline Corrected Total & Berpikir_kreatif & 5582,583 & 59 & & \\
& Hasil_belajar & 5252,733 & 59 & & \\
\hline
\end{tabular}

a. $\mathrm{R}$ Squared $=.114($ Adjusted R Squared $=.098)$

b. $\mathrm{R}$ Squared $=.317$ (Adjusted R Squared $=.305)$

Untuk rumusan masalah pertama, perhatikan tabel 10 kolom Corrected Model nilai $\mathrm{F}=7,428$ untuk variabel berpikir kreatif dengan nilai sig. $=0,008<0,05$ (signifikan) berarti terdapat pengaruh model pembelajaran project-based learning berbasis pendekatan STEM terhadap kemampuan berpikir kreatif. Selanjutnya untuk menjawab rumusan masalah kedua, perhatikan nilai $\mathrm{F}=26,899$ untuk variabel hasil belajar dengan nilai sig. $=0,000<0,05$ (signifikan) berarti terdapat pengaruh model pembelajaran project-based learning berbasis pendekatan STEM terhadap hasil belajar matematika.

Tabel 11. Hasil Analisis Bersama-sama Multivariate Tests ${ }^{a}$

\begin{tabular}{|c|c|c|c|c|c|c|}
\hline Effect & & Value & $\mathrm{F}$ & $\begin{array}{l}\text { Hypothesis } \\
\text { df }\end{array}$ & $\begin{array}{l}\text { Error } \\
\text { df }\end{array}$ & Sig. \\
\hline \multirow[t]{4}{*}{ Intercept } & Pillai's Trace & ,991 & $3258,208^{b}$ & 2,000 & 57,000 & 0,000 \\
\hline & Wilks' Lambda & ,009 & $3258,208^{b}$ & 2,000 & 57,000 & 0,000 \\
\hline & Hotelling's Trace & 114,323 & $3258,208^{b}$ & 2,000 & 57,000 & 0,000 \\
\hline & Roy's Largest Root & 114,323 & $3258,208^{b}$ & 2,000 & 57,000 & 0,000 \\
\hline \multirow[t]{4}{*}{ Kelas } & Pillai's Trace &, 343 & $14,881^{\mathrm{b}}$ & 2,000 & 57,000 & 0,000 \\
\hline & Wilks' Lambda & ,657 & $14,881^{\mathrm{b}}$ & 2,000 & 57,000 & 0,000 \\
\hline & Hotelling's Trace &, 522 & $14,881^{b}$ & 2,000 & 57,000 & 0,000 \\
\hline & Roy's Largest Root &, 522 & $14,881^{\mathrm{b}}$ & 2,000 & 57,000 & 0,000 \\
\hline
\end{tabular}

Untuk menjawab rumusan masalah ketiga, perhatikan tabel 11, nilai F untuk Pillai's Trace, Wilks' Lambda, Hotelling's Trace, dan Roy's Largest Root memiliki nilai sig. $=0,000<0,05$ (signifikan), yang berarti bahwa terdapat pengaruh model pembelajaran project-based learning berbasis pendekatan STEM secara bersama-sama terhadap kemampuan berpikir kreatif dan hasil belajar matematika.

\section{Pembahasan}

Pengaruh model pembelajaran project-based learning berbasis pendekatan STEM terhadap kemampuan berpikir kreatif. Pendekatan STEM memiliki keunggulan dapat memotivasi peserta didik untuk belajar matematika, hal ini sejalan dengan hasil penelitian Carlisle dan Weaver (2018) \& teori yang dikemukakan oleh Association of American Universities (2013). Motivasi yang tinggi dapat mendorong seseorang untuk melakukan suatu tindakan tertentu. Dalam proses pembelajaran peserta didik dengan senang hati dan atas 
kemauan sendiri melakukan aktivitas proyek yang telah ditugaskan kepadanya. Aktivitas yang dilakukan dengan sungguh-sungguh dan secara langsung oleh peserta didik berdampak pada pola pikir dan logika yang secara tidak langsung diasah ketika mengerjakan tugas proyek (Capraro, dkk., 2016). Demikian pula pendekatan STEM yang mengintegrasikan sains, teknologi, engineering, dan matematika untuk menyelesaikan permasalahan kontekstual yang diberikan dapat memotivasi siswa lebih jauh karena mereka mampu menghubungkan konsepkonsep yang diperoleh di kelas dengan dunia nyata. Aspek matematika pada pendekatan STEM secara tidak langsung dapat mengembangkan kemampuan berpikir kreatif. Pola pikir, logika, dan penalaran yang dilatih secara terus menerus dapat memicu kemampuan berpikir kreatif peserta didik. Dengan demikian, apa bila model pembelajaran project-based learning berbasis pendekatan STEM diimplementasikan secara terus menerus dalam pembelajaran matematika dapat mengembangkan kemampuan berpikir kreatif peserta didik.

Pengaruh model pembelajaran project-based learning berbasis pendekatan STEM terhadap hasil belajar matematika. Hasil belajar matematika dipengaruhi oleh berbagai faktor yang dikelompokkan menjadi faktor internal dan faktor eksternal. Secara internal model pembelajaran project-based learning berbasis pendekatan STEM dapat memotivasi peserta didik untuk belajar matematika dengan sungguh-sungguh. Artinya secara tidak langsung minat belajar matematika meningkat. Demikian pula model pembelajaran project-based learning berbasis pendekatan STEM dapat mempengaruhi faktor ekternal seperti lingkungan belajar yang kondusif, suasana belajar menyenangkan, bahkan kolaborasi antara peserta didik juga dapat memicu suasana pembelajaran yang dirindukan oleh peserta didik untuk belajar bersamasama. Aspek teknologi dalam pendekatan STEM juga merupakan daya tarik tersendiri yang mampu menggugah semangat belajar peserta didik untuk menyelesaikan permasalahan kontekstual. Hal ini sejalan dengan pendapat Nurfadhilah \& Zubaidah Amir MZ (2018), yang menyatakan pembelajaran yang dilakukan dengan kontekstual dapat meningkatkan hasil belajar matematika. Dengan demikian, model pembelajaran project-based learning berbasis pendekatan STEM mampu meningkatkan faktor internal dan eksternal yang mempengaruhi hasil belajar matematika, sehingga hasil belajar matematika juga lebih baik.

Pengaruh model pembelajaran project-based learning berbasis pendekatan STEM secara bersama-sama terhadap kemampuan berpikir kreatif dan hasil belajar. Swandewi, dkk. (2019) menyatakan bahwa kemampuan berpikir kreatif dapat dioptimalkan melalui pembelajaran matematika berbasis masalah kontekstual. Berpikir kreatif merupakan kemampuan untuk menghasilkan gagasan baru yang tidak rutin, mampu melihat masalah dari berbagai sudut pandang berbeda, serta mampu menghasilkan ide-ide yang banyak dan berbeda dengan orang 
lain. Dalam pembelajaran matematika, kemampuan berpikir kreatif menjadi fondasi utama untuk mencapai hasil belajar matematika dengan baik. Model pembelajaran project-based learning berbasis pendekatan STEM telah terbukti dapat mengembangkan kemampuan berpikir kreatif karena mampu membangun motivasi dan minat belajar yang kuat. Demikian pula model pembelajaran project-based learning berbasis pendekatan STEM mampu meningkatkan faktorfaktor yang mempengaruhi hasil belajar matematika yaitu faktor internal dan faktor eksternal, sehingga hasil belajar matematika dengan sendirinya juga meningkat (Chesky \& Wolfmeyer, 2015). Dengan kata lain bahwa penerapan model pembelajaran project-based learning berbasis pendekatan STEM secara bersama-sama dapat meningkatkan kemampuan berpikir kreatif dan hasil belajar matematika.

\section{Simpulan}

Terdapat pengaruh model pembelajaran project-based learning berbasis pendekatan STEM terhadap kemampuan berpikir kreatif, terdapat pengaruh model pembelajaran projectbased learning berbasis pendekatan STEM terhadap hasil belajar matematika, dan terdapat pengaruh model pembelajaran project-based learning berbasis pendekatan STEM secara bersama-sama terhadap kemampuan berpikir kreatif dan hasil belajar matematika. Dengan demikian guru matematika direkomendasikan untuk mengimplementasikan model pembelajaran project-based learning berbasis pendekatan STEM untuk meningkatkan hasil belajar matematika siswa dan mengembangkan kemampuan berpikir kreatif.

Pada penelitian selanjutnya, perlu dikaji pengembangan model asesmen yang sesuai dengan model pembelajaran project-based learning berbasis pendekatan STEM. Hal itu dimaksudkan agar model pembelajaran yang digunakan sejalan dengan model asesmen yang digunakan untuk mengukur hasil belajar, karena tidak mudah bagi guru-guru matematika untuk mengembangkan asesmen berbasis proyek yang bersifat kontekstual.

\section{Referensi}

Aldabbus, S. (2018). Project-based learning: Implementation \& challenges. International Journal of Education, Learning and Development, 6(3), 71-79.

Association of American Universities. (2013). Framework for systemic change in undergraduate STEM teaching and learning. Diambil dari https://www.aau.edu/sites/default/files/STEM\%20Scholarship/AAU_Framework.pdf.

Bassham, G., Irwin, W., Nardone, H., \& Wallace, J. M. (2013). Critical thinking: A student's introduction (5th ed.). New York, NY: McGraw-Hill.

Capraro, M. M., Whitfield, J. G., Etchells, M. J., Robert M., \& Capraro. (2016). A companion to interdisciplinary STEM project-based learning: For educators by educators (second edition). Rotterdam: Sense Publishers. https://doi.org/10.1007/978-94-6300-485-5. 
Carlisle, D.L., \& Weaver, G.C. (2018). STEM education centers: catalyzing the improvement of undergraduate STEM education. International Journal of STEM Ed 5(47), 1-21, https://doi.org/10.1186/s40594-018-0143-2.

Changwong, K., Sukkamart, A., \& Sisan, B. (2018). Critical thinking skill development: Analysis of a new learning management model for Thai high schools. Journal of International Studies, 11(2), 37-48. https://doi.org/10.14254/2071-8330.2018/11-2/3.

Chesky, N. Z. \& Wolfmeyer, M. R. (2015). Philosophy of STEM education: A critical investigation. New York: Palgrave Macmillan. https://doi.org/10.1057/9781137535467.

Chiang, C. L., \& Lee, H. (2016). The effect of project-based learning on learning motivation and problem-solving ability of vocational high school students. International Journal of Information and Education Technology, 6(9), 709-712. https://doi.org/10.7763/IJIET.2016.V6.779.

Ernest, P. (2015). The social outcomes of learning mathematics: Standard, unintended or visionary? International Journal of Education in Mathematics, Science and Technology, 3(3), 187-192. https://doi.org/10.18404/ijemst.29471.

Hasani, A., Hendrayana, A., \& Senjaya, A. (2017). Using project-based learning in writing an educational article: An experience report. Universal Journal of Educational Research 5(6), 960-964. https://doi.org/10.13189/ujer.2017.050608.

Hidayat, W. \& Veny Triyana Andika Sari. (2019). Kemampuan berpikir kritis matematis dan adversity quotient siswa SMP. Jurnal Elemen, 5(2), 242-252. https://doi.org/10.29408/jel.v5i2.1454.

Kristiyani, E. (2018). Increasing interest and mathematical learning outcome in mathematic of trigonometry basic competence (KD) by using reciprocal teaching model for students of class X MIPA 4 SMA Negeri 5 Magelang in the even semester of academic year 2017/2018. Indonesian Journal of Education and Learning, 2(1), 142-147.

Kristanti, Y. D., Subiki, \& Handayani, R. D. (2016). Model pembelajaran berbasis proyek (project-based learning model) pada pembelajaran fisika di SMA. Jurnal Pembelajaran Fisika, 5(2), 122-128.

Mali, Y. C. G. (2016). Project-based learning in Indonesian EFL classrooms: From theory to practice. IJEE (Indonesian Journal of English Education), 3(1), 89-105. https://doi.org/10.15408/ijee.v3i1.2651.

Mawardhiyah, K., \& Manoy, J. T. (2018). Literasi matematika siswa SMP dalam menyelesaikan soal PISA berdasarkan adversity quotient. MATHEdunesa, 7(3), 638-643.

Nafiah, Y. N., \& Suyanto, W. (2014). Penerapan model problem-based learning untuk meningkatkan keterampilan berpikir kritis dan hasil belajar siswa. Jurnal Pendidikan Vokasi, 4(1), 125-143. https://doi.org/10.21831/jpv.v4i1.2540.

Nilasari, N. T. \& Anggreini, D. (2019). Kemampuan literasi matematika siswa dalam menyelesaikan soal PISA ditinjau dari adversity quotient. Jurnal Elemen, 5(2), 206-219. https://doi.org/10.29408/jel.v5i2.1342.

Nurfadhilah \& Zubaidah Amir MZ. (2018). Kemampuan penalaran matematis melalui pembelajaran contextual teaching and learning (CTL) pada siswa SMP. Jurnal Elemen, 4(2), 171-182. https://doi.org/10.29408/jel.v4i2.714.

Redkar, S. (2012). Teaching advanced vehicle dynamics using a project-based learning (PBL) approach. Journal of STEM Education: Innovations and Research, 13(3), 17-29.

Sudiarta, I. G. P., \& Widana, I. W. (2019). Increasing mathematical proficiency and studentscharacter: Lesson from the implementation of blended learning in junior high school in Bali. IOP Conf. Series: Journal of Physics: Conf. Series1317 (2019) 012118. https://doi.org/10.1088/1742-6596/1317/1/012118. 
Swandewi, N.L.P., Gita, I.N., \& Suarsana, I.M. (2019). Pengaruh model quantum learning berbasis masalah kontekstual terhadap kemampuan berpikir kreatif siswa SMA. Jurnal Elemen, 5(1), 31-42. https://doi.org/10.29408/jel.v5i1.932.

Wahyu, R. (2016). Implementasi model project-based learning (PJBL) ditinjau dari penerapan Kurikulum 2013. Teknoscienza, 1(1), 50-62.

Widana, I. W. (2020). The effect of digital literacy on the ability of teachers to develop HOTSbased assessment. Journal of Physics: Conference Series 1503(2020) 012045. https://doi.org/10.1088/1742-6596/1503/1/012045.

Zhou, A., Kolmos, A., Nielsen, \& Frederik, D. (2012). A problem and project-based learning (PBL) approach to motivate group creativity in engineering education. International Journal of Engineering Education, 28(1), 3-16. 